\title{
Assessment of Energy and Environment Footprint of a Proposed Wind Farm in Western Coast of Libya Using LCA
}

\section{Abdelbari Elmariami}

7th April University: University of Zawia

Wedad Elosta ( $D$ e_wedad@hotmail.com)

Center for Solar Energy Research and Studies https://orcid.org/0000-0003-3573-2546

Mohamed Elfleet

King Abdulaziz University

Yusef Khalifa

Center for solar energy research and studies

\section{Research Article}

Keywords: Life cycle analysis, wind energy, greenhouse gases, zero carbon, energy savings

Posted Date: November 30th, 2021

DOI: https://doi.org/10.21203/rs.3.rs-1095513/v1

License: (a) (i) This work is licensed under a Creative Commons Attribution 4.0 International License.

Read Full License 


\section{Abstract}

Wind offers Libya an abundant, domestic, and currently untapped carbon free energy resource. This paper describes LCA model of assessment for the identified wind farm near the coastal city Zawia in Libya. The city has been affected by GHG emissions associated with Oil refinery facilities for the last five decades. The model study investigates the life cycle energy performance of the wind farm and the environmental impact category indicators at midpoint level, specifically; acidification and climate change.

LCA was conducted to the proposed utility-scale wind farm with total estimated power of $20 \mathrm{MW}$, the assessment was conducted using the principles of the international standards ISO14040 and 14044.

The results demonstrated that the amount of $\mathrm{CO}_{2}$ that can be avoided from the proposed wind farm would be about $2 \mathrm{MtCO}_{2}$. The other emissions that could be avoided are $352.7 \mathrm{~kg} \mathrm{CH}_{4}$ and $63.5 \mathrm{~kg} \mathrm{~N} \mathrm{~N}_{2} \mathrm{O}$. This would contribute to the alleviation of global climate change and global sustainability energy system which is recommended by UN SDG7.

\section{Introduction}

The Study Area

The proposed location of the wind farm is in Zawia city, 40-km west of Tripoli the capital city of Libya. The proposed wind farm consists of ten wind turbines. The site is located 6 kilometers east of Zawia, specifically in the Guddaim region. The area is located in the longitude 12.47 east and latitude 32.47 north. Fig. (2) depicts the proposed wind farm site, the area surrounded by red color. Zawia does not have the best wind resource in Libya, but it has reasonable wind potential in addition to other factors that favors the development of the proposed wind farm, as follows:

- Good wind resource.

- Availability of power lines and substations to import generated wind energy into the grid.

- A large territory that should allow a choice of places for the wind farm construction.

- Remoteness from populated places.

- Possibilities for extending the installed capacity in the future.

- Availability of transport, communications and sufficient remoteness from the district's busiest (main) motor road.

- Proximity to the consumers and small electricity transmission losses.

This paper also describes assessment process to evaluate the environmental burdens associated with the greenhouse emissions of wind farm facilities to generate $20 \mathrm{MW}$ of electricity. 
Libya has an estimated total carbon dioxide equivalent emission of close to $53 \mathrm{Mt}$ per year. Most of this occurs in the energy demand and the transport sectors. Most countries in Europe have achieved substantial reductions through the decarbonization of electricity supply.

Wind power is one of the fastest growing renewables. Its usage is on the rise worldwide, through technology innovations and economies of scale and its role on the road to net zero energy. Worldwide total installed wind power generation capacity onshore and offshore has increased by a factor of 75 in the past two decades, jumping from $7.5 \mathrm{GW}$ in 1997 to $743 \mathrm{GW}$ in 2020,according to GWEC (GWEC, 2021), helping to avoid over 1.1 billion tons of $\mathrm{CO}_{2}$ globally.

Libya has abundance of wind and solar potential (web, 2021a), which is not tapped yet. It should be harnessed and exploited to face global environmental challenges in addition to diverse its energy sources and economy. The last period of political unrest and conflict affected the power generation sector and caused electric network instability and lag of any national plans for real contribution to renewable energy in the national energy mix. There is a strategic plan that was devised through (2018-2030) to deploy 6.6 GW of renewable energy by 2030 (KFW, GIZ, IRENA, 2021), which hopefully will be taken seriously and implemented.

\section{Background}

There is a debate about the environmental aspects of installing large wind energy converters, which raises a concern for investors and authorities to construct wind power plants. Life cycle assessment (LCA) is an international standard (ISO) approved tool devised to compare different energy systems or technologies and assess their environmental impacts through life cycle in order to help decision makers to choose best technology to be used. It addresses environmental aspects, including emissions footprint, and secondary raw material extraction at the end of life by introducing the circular economy (CE) approach.

LCA of wind turbines, onshore and offshore wind farm was tackled in several studies. Crawford (Crawford, 2019) studied the effect of the size of the wind turbines on their life cycle and greenhouse emissions and concluded that the size of wind turbine is not an important factor to optimize the life cycle energy performance, while Tremeac and Meunier (Tremeac \& Meunier, 2009) compared two wind turbines with considerably different capacities, one of $4.5 \mathrm{MW}$ and the other is $250 \mathrm{~W}$, and concluded that, the larger the rated output power of the wind turbine, the lower the $\mathrm{CO}_{2}$ emissions per kWh generated. Guezuraga et al. (Guezuraga et al., 2012) compared two different wind energy technologies, one is 1.8 MW gearless and the other is $2 \mathrm{MW}$ with a gearbox. They used Global Emission Model of Integrated System (GEMIS) simulation software to assess the life cycle of the wind turbine, and found that energy requirement of manufacturing phase represents the highest share $84 \%$ of the total life cycle and the tower accounts for $55 \%$ of total wind turbine production. They estimated the energy payback time as 7 months and the $\mathrm{CO}_{2}$ emissions as $9 \mathrm{~g} / \mathrm{kWh}$, concluding that renewable energy and specifically wind energy is the cleanest source of energy, this is conclusive with other studies (Web, 2021a). Rashedi et al, (Rashedi et al, 
2013) performed a life cycle impact analysis (LCIA) of three wind farms: one onshore with horizontal axis wind turbines, one offshore with horizontal axis wind turbines, and another is vertical axis wind turbines wind farm. They concluded that vertical axis wind farm generates lowest impacts per unit electricity followed by horizontal offshore and last the horizontal onshore farms. Wagner et al. (Wagner et al., 2011) and (Weinzettel et al., 2009) studied floating offshore wind turbines by LCA means. In terms of the size of wind turbines, again, the study revealed that the larger the rated output power of the wind turbine, the lower the $\mathrm{CO}_{2}$ emissions per kWh. In contrast, (Kadiyala et al., 2017) performed a statistical evaluation of wind energy LCA studies and determined that for wind turbines greater than $0.25 \mathrm{MW}$ capacity, onshore turbines have higher GHG emissions (15.98 - $17.12 \mathrm{gCO} 2 \mathrm{eq} / \mathrm{kWh}$ ) compared to offshore wind turbines (12.9 - $7.61 \mathrm{gCO} 2 \mathrm{eq} / \mathrm{kWh}$ ). Lenzen and Wachsmann (Lenzen \& Wachsmann, 2004) indicated that that the location and geographical variability play a major role in determining the life cycle environmental impacts of wind farms. They determined that in addition to geographical location, the life cycle environmental impact of wind energy is also dependent on major parameters such as type of wind turbine axis of rotation (horizontal or vertical), capacity factor, and rated power.

In the US, Chipindula et al, (2018) conducted a LCA study in Texas, USA, with attempts to quantify the relative contribution of different phases of life cycle impacts for three different sites (onshore, shallowwater, and deep-water, in Texas) using software (SimaPro). They indicated that material extraction and processing have the dominant impact with contribution of $72 \%$ for onshore site, $58 \%$ for shallow water and $82 \%$ for deep-water location across the 15 midpoint impact categories. The payback period for $\mathrm{CO}_{2}$ was estimated as 6 to 14 months and energy payback period 6 to 17 months with shorter payback periods to onshore sites. The greenhouse gas emissions (GHG) were in the range of $5-7 \mathrm{gCO}_{2} \mathrm{eq} / \mathrm{kWh}$ for the onshore location, 6-9 $\mathrm{CO}_{2} \mathrm{eq} / \mathrm{kWh}$ for the shallow-water location, and 6-8 CO2eq/ $\mathrm{kWh}$ for the deepwater location. Haapala and Prempreeda (Haapala \& Prempreeda, 2014) made an LCA for two 2 MW onshore wind turbines located between the states of Oregon and Washington. They suggested that the manufacturing phase accounts for the highest share $(78 \%)$ of the life cycle environmental impact for supply chains in the U.S. They estimated the energy payback period to be 5.2 and 6.4 months for the two turbines and identified that the tower has the highest contribution to environmental impacts followed by the rotor and nacelle. In Brasil, Kerstin B. Oebels and Sergio Pacca (Oebels \& Pacca, 2013), assessed the life cycle of an onshore wind farm on the northeastern coast of Brazil, with aim to identify the main sources of $\mathrm{CO}_{2}$ eq emissions. They found that $\mathrm{CO}_{2}$-intensity during the life cycle of the wind farm is $7.1 \mathrm{~g}$ $\mathrm{CO}_{2} / \mathrm{kWh}$ and the bulk emissions are from production phase over $(90 \%)$, while the transportation phase contribution only $6 \%$ of the $\mathrm{CO}_{2}$-emissions. In South Asia, (Nian et al, 2019) calculated LCOE of offshore wind in Singapore and found that offshore wind is less competitive than PV and that it could reach parity with solar PV at a distance of $300 \mathrm{~km}$ offshore under annual mean wind speed of 6-8 m/s. In India (Jani \& Rangan, 2018) Jani Das .. et al performed life cycle analysis of energy requirement and carbon footprint for two large scale grid connected wind farms with two different technology wind turbines at two different locations to study the impact of load factor, recycling and transportation. 
Several case studies were conducted in Europe. Pavel Petruneac ( Pavel Petruneac, 2015) compared onshore and offshore wind turbines in UK and concluded that $\mathrm{CO}_{2}$ emissions is the most important parameter in the LCA and the major contribution of these emissions from manufacturing and transportation processes and the payback period for onshore is 0.47 year while for offshore is 1.94 or almost two years and in general the carbon footprint is far less than conventional electricity. Martínez et al (Martínez et al, 2008) analyzed a $2 \mathrm{MW}$ wind turbine that was installed in Munilla wind farm in Spain; during its life cycle from cradle to grave, considering all phases. They evaluated the environmental advantages and impacts of manufacturing and recycling process. In France (Palomo \& Gaillardon, 2009) LCA has been carried out to evaluate the potential of environmental impacts associated with electricity generation from a French onshore wind farm consisting of five units of 3MW each. They calculated the energy payback time (EPBT) as (1.03 yr.), the energy intensity (El) as (0.051 kWh used/ kWh produced) and $\mathrm{CO}_{2}$ intensity (11.77 $\mathrm{g}$ of $\mathrm{CO}_{2} / \mathrm{kWh}$ produced) for wind turbine life time of 20 years and performed sensitivity analysis for life time of 40 years. In Italy (Ardente, 2008) a case study of a wind farm located in the South Italy (Sicily) was conducted to investigate the different steps of the life cycle. In Greece (Abeliotis \& Pactiti, 2014) Abeliotis \& Pactiti assessed the environmental impact of an onshore wind farm of 4 wind turbines $850 \mathrm{~kW}$ each and determined the $\mathrm{CO}_{2}$ intensity as $4.1 \mathrm{~kg} / \mathrm{MWh}$ and the energy payback period as 7 months.

There is a lack of LCA studies to assess wind energy projects in Africa and specifically in North Africa, only two studies were conducted; one in Libya (Al-Behadili \& El-Osta, 2015) and the other in Ethiopia (Karkour et al., 2021). In Libya, Al-Behadili and El-Osta evaluated the primary energy consumption and carbon footprint to a wind farm on the northern coast of Libya (Dernah) and assessed the effect of recycling. The LCA revealed that energy payback period is 5.7 months, and the pay back ratio is 42 . The CO2 intensity is $10.4 \mathrm{~g} / \mathrm{kWh}$ without recycling process while with recycling is $4.65 \mathrm{~g} / \mathrm{kWh}$ of energy generated. This study, in addition to previous one, will provide knowledge of such practice in this region.

\section{Methodology}

To conduct LCA study, there are two modelling approaches depending on scope and goal of the study; Consequential model and Attributional model. In this study Consequential approach was used in system modelling. It can be used for full share of activities that might change during production, consumption and disposal of a product (Maria Tsagkaraki, 2015; Web, 2021c). Each material in a wind turbine is traced back to its manufacturing process. The energy input required to produce each material and the emissions resulting from the production are assessed. The mass of each material is then multiplied by the appropriate energy and emission factor. In the final life cycle assessment, the energy consumed and emissions resulting from each material are summed over the entire turbine system.

For the purposes of this LCA looking at the wind farm system, a mathematical scheme used in previous studies (Dow, 2015) and (Aboulqassim, 2017) has been applied to evaluate wind farm energy performance and calculate the emission intensities and the payback time. 


\subsection{LCA Conceptual Framework}

LCA framework is based on ISO 14040 and 14044 principles. The assessment was carried out in four phases, as follows:

1. goal and scope definition;

2. inventory analysis: compiling the relevant inputs and outputs of a product system;

3. impact assessment: evaluating the potential environmental impacts associated with those inputs and outputs; and

4. interpretation: the procedure to identify, qualify, check and evaluate the results of the inventory analysis and impact assessment phases in relation to the objectives of the study.

\subsection{Functional Unit:}

In order to quantify the environmental impacts of the proposed wind farm it is necessary to relate the impacts to electricity generated by the wind farm in order to make fair comparison of different types of energy production technologies. The functional unit in this study is taken as $1 \mathrm{kWh}$ of electricity delivered to electric grid from the proposed wind farm.

\subsection{Data Collection:}

The data of the wind turbines was compiled from different sources. The material and energy used for production of different wind turbines' components was collected from literature and from the selected wind turbine manufacturer (Gamesa).

\subsection{System Boundaries:}

In this study, the system boundaries were limited to the processes indicated in Figure (2), which incorporates the life cycle of the energy consumption through the proposed wind farm. The system boundaries included construction of the main components of wind turbines, transportation to the wind farm, installation of different components, O\&M as well as dismantling of the wind farm. The distribution of electricity generated by the wind farm, and electricity network are outside of the system boundaries.

\subsection{Scope of Lac}

- Construction

- Operation

- Decommissioning

- Electricity output of the plant over its life time.

\subsection{Points for consideration}


1- Influence of life-time, load factor and power rating

2- Analysis of component level:

a. Rotor blades

b. Transmission and accessories

c. Generator (electronic controls and cables)

d. Tower including Yaw

e. Foundation.

3- Influence of methodology and, scope, and maturity

4- Influence of technology

5- Influence of production in country of manufacturing

6- Influence of recycling and overhaul.

\subsection{Key Input assumptions:}

Life cycle inventory data are obtained from different references concerning the specific energy of the different materials and related emissions intensity of each material, in addition to material weight of the selected wind turbine from the manufacture Gamesa, as stated in related sections of this study.

The assumptions made in this analysis are as follows:

1- The energy consumption of the operation and maintenance phase is negligible.

2- As it is difficult to get the energy consumed and emissions data for different processes during lifetime of wind turbines in different countries, the energy processes system has been assumed to follow Danish conditions.

3- Emissions during operation and maintenance are ignored.

4- Energy production from the wind farm depended (based) on a previous study (Dow, 2015)

\subsection{Lifecycle Inventory:}

Life cycle inventory analysis is defined by ISO standards as the phase of life cycle assessment that involves compilation and quantification of input and output of a product though its life cycle. It involves energy and material consumption of wind turbines during its life cycle as well as related emissions in order to assess its effects on the environment.

Wind turbines consist of several components and sub-components. The lifecycle inventory included in this study are as follows:

\subsubsection{Description of the wind turbines:}


The selected wind turbine for the proposed wind farm is Gamesa (G114-2.0MW) (Gamesa, 2017). It has a- 2.0 MW rated power, with a three-bladed rotor and advanced aerodynamic design for highest efficiency in low-wind sites and lowest noise. The rotor diameter is $114 \mathrm{~m}$, and the swept area is $10,207 \mathrm{~m}^{2}$. The tower is tapered with a height of $93 \mathrm{~m}$. The expected life time of the wind turbine is 20 years and the availability is $98 \%$.

\subsubsection{Inventory of wind turbine Gamesa (G 114- 2MW) Components}

The materials that constitute the different parts of the wind turbines are recycled, while the concrete which is used for foundation construction (about $72 \%$ of all material) is not recycled and it is completely landfilled. The mass of concrete and steel used in a foundation can vary significantly based on soil conditions from site to the other. Table (1) shows weight of materials that compose the wind turbine Gamesa (G114-2.0 MW).

Table (1) Weight of materials of different parts of wind turbine (G114-2.0MW) (Gamesa, 2017)

\begin{tabular}{|lll|}
\hline Material & Weight $(\mathbf{k g})$ & $\%$ \\
\hline Low alloyed steel & 245049.27 & 15.96 \\
\hline High alloyed steel & 32319.27 & 2.1 \\
\hline Cast iron & 48375 & 3.15 \\
\hline Reinforced steel & 41043.7 & 2.67 \\
\hline Copper & 1512.74 & 0.1 \\
\hline Aluminum & 4772.62 & 0.31 \\
Glass fiber & 22689.55 & 1.48 \\
\hline Brass & 33.9 & 0.002 \\
Polymers & 4568.34 & 0.3 \\
\hline GRP (glass reinforced plastic) & 2605.39 & 0.17 \\
Concrete & 1112856 & 72 \\
\hline Epoxy resin & 10743.41 & 0.7 \\
\hline Miscellaneous & 9173.86 & 0.6 \\
\hline Total & 1535743.48 & $100 \%$ \\
\hline
\end{tabular}

\subsection{Transportation impact.}

The transport of all the raw materials to the manufacturer and from the manufacturer to the location of the wind farm was considered. Transportation impacts were evaluated based on energy consumption 
and related emissions released during extraction of fuel and its combustion during transportation of the components to the site as well as the energy consumed through this process. This type of energy depends on type of transportation and on type of fuel used, in addition to other factors that might affect estimating the energy consumed on this phase. Therefore, it was estimated as a percentage of energy consumed in manufacturing process (Razdan \& Garrett, 2015).

\subsection{End of Life:}

Recycling process accounts for a large part of the turbine materials' weight. The remaining of these materials will be landfilled. The estimated energy for this process, and related emissions are described in section (5.3).

\section{Life Cycle Impact Assessment}

Environmental impacts expected to arise from the proposed wind farm was studied and assessed. The analysis covered the entire life cycle of the proposed wind farm considering all stages. The assessment is based on type and weight of all materials used for manufacturing different parts of the wind turbines at the wind farm.

The primary energy requirements were estimated according to equations in the literature as well as life cycle energy and carbon footprint and other emissions as depicted in the following sections. The goal and scope were defined and inventory analysis was performed and the results were evaluated and assessed according to the following sections.

The total energy required for the proposed wind farm consists of energy required for construction of wind farm (mainly wind turbine rotor, nacelle, tower and other components), operation and maintenance and finally energy for disposing the power plant (Aboulqassim, 2017).

The estimated energy produced by the wind farm reported from a previous study (Dow, 2015), where technical and economic analysis were performed for the proposed wind farm. A comparative study between three types of wind turbines was done in order to choose the best wind turbine for the site. Gamesa (G114-2.0MW) was found to be the best for the proposed wind farm (Dow, 2015).

\subsection{Energy consumed on manufacturing process}

Energy consumed on manufacturing of the wind turbine can be estimated from the knowledge of the weight of material involved in the different parts of the wind turbine, as depicted in table (2-1) for the selected wind turbine (G114-2.0MW) and the specific energy of each material (David R. Wilburn, 2011).

\subsection{Energy consumed on Recyclability process}

In estimating the energy consumed on recycling process, the percentage of materials that can be recycled of each part of the wind turbine, was adopted in order to calculate the recyclability factor. This factor depends on the weights of the main components, especially the tower, which contributes to the highest 
share (Gamesa, 2017). Then the energy spent on the recyclability process of these materials can be determined with knowledge of the specific energy.

\subsection{Landfilling operation}

Recycling process accounts for a large part of the wind turbine weight from several materials. The remaining of these materials will be landfilled. The energy consumed on landfill operation can be determined by knowledge of the weight of the remaining parts of the wind turbine for landfilling operations and the specific energy of each material.

\subsection{Transportation}

The transport of all the raw materials to the manufacturer and from the manufacturer to the location of the wind farm was considered. It is hard to estimate this type of energy. It depends on type of transportation and on type of fuel used, in addition to other factors that might affect estimating the energy consumed on this phase. So, it was estimated as a percentage of energy consumed in manufacturing process. The following percentages were adopted (Aboulqassim, 2017):

1- Transport between Company and its suppliers $1.692 \%$ from consumed energy

2- Transport to wind farm site $3.912 \%$ from consumed energy

3- End of life transport $0.206 \%$ from consumed energy

This would lead to total percentage of energy consumed on the transport process as $5.81 \%$ of the total energy consumed on the wind turbine during the manufacturing process. Therefore, the total energy consumed on transport can be determined.

\subsection{The overall energy consumed on the turbine}

The total primary energy consumed on the turbine through its life cycle will be the summation of energy consumed on all phases from cradle to grave.

\section{Energy Performance And Emissions Footprint Analysis}

There are different indicators that can be used to assess the energy performance of wind energy farm. The main energy indicators that were assessed are: energy payback time and energy payback ratio, energy intensity. The environmental footprint analysis was concentrated on global warming and acidification effect.

\section{1- Energy payback period:}

The energy payback period (EPBP) is a measure of the time or number of years required for a wind turbine to produce an amount of energy equivalent to the energy consumed during its life cycle phase 
(cradle to grave). It is defined as the ratio of the total primary energy consumed during life cycle and electric energy produced by the wind turbine per year during system operation.

\subsection{Energy payback Ratio and energy intensity.}

The energy payback ratio is defined as the ratio of the energy produced by the wind turbine/ wind farm during its life time of operation to the LC energy consumed on the wind turbine/ wind farm.

The energy intensity is defined as the ratio of the primary energy consumed during life cycle to the electric energy produced by the wind power plant during its life time $\left(\mathrm{kWh} \mathrm{h}_{\text {prim }} / \mathrm{kWh}_{\mathrm{e}}\right)$.

\subsection{Life Cycle Emissions (LCE)}

Wind energy does not pose any threat to the atmosphere during its energy generation phase. However, energy in various stages is being consumed, such as during manufacturing process, construction, commissioning and decommissioning phases of the project. In the Life Cycle Emission (LCE) analysis, these emissions will be considered during all these phases of the turbine's life cycle. The emissions are calculated as the ratio of emission, e.g. $\mathrm{CO}_{2}$, in grams to the electric energy produced by the wind turbine/ or wind power plant $\left(\mathrm{gm} \mathrm{CO}_{2} / \mathrm{kWh}_{\mathrm{e}}\right)$.

\subsubsection{Emission intensity}

In considering emissions in transportation phase, it was assumed that light duty vehicles (LDV) would be used during regular operations of turbines. Table (2) describes the emission factors involved in different transportation modes (Aboulqassim, 2017). Using these values, the amount of emissions from transport operations per kilowatt hour can be determined.

Table (2) Emission from transport $(\mathrm{kg} / \mathrm{MJ})$

\begin{tabular}{|lllllllll|}
\hline Mode & $\mathrm{MJ}$ & $\mathrm{CO}_{2}$ & $\mathrm{CO}$ & $\mathrm{CH}_{4}$ & $\mathrm{~N}_{2} \mathrm{O}$ & $\mathrm{SO}_{2}$ & $\mathrm{NO}_{\mathrm{X}}$ & MNVOC \\
\hline $\mathrm{HDV} / \mathrm{km}$ & 3.41 & 0.076 & $7.5 \mathrm{E}-4$ & $4.5 \mathrm{E}-5$ & $2.9 \mathrm{E}-5$ & $2.7 \mathrm{E}-5$ & $1.6 \mathrm{E}-3$ & $3.3 \mathrm{E}-4$ \\
$\mathrm{LDV} / \mathrm{km}$ & 5.08 & 0.35 & $6.4 \mathrm{E}-4$ & $8.9 \mathrm{E}-6$ & $2.8 \mathrm{E}-5$ & $4 \mathrm{E}-5$ & $8.2 \mathrm{E}-4$ & $3.5 \mathrm{E}-4$ \\
\hline
\end{tabular}

Then the total emissions $\left(\mathrm{CO}_{2}, \mathrm{SO}_{2}, \mathrm{NO}_{\mathrm{x}}, \mathrm{N}_{2} \mathrm{O}, \mathrm{CH}_{4}, \mathrm{CO}\right.$, and NMVOC) from different processes (manufacturing, recycling, landfill, and transport), can be determined by adding all emissions.

\subsubsection{Carbon Payback time:}

Carbon payback time $\left(\mathrm{CO}_{2} \mathrm{PBT}\right)$ determines how long the turbine would need to operate before the electricity it generates can be considered carbon free or neutral. To calculate $\mathrm{CO}_{2} \mathrm{PBT}$, life cycle GHG' emissions from a wind turbine are compared to amount of GHG of conventional power plant that would produce same amount of electricity the turbine produces in its life time. It is defined as the period of time 
that a wind turbine to avoid $\mathrm{CO}_{2}$ generated by fossil fuel that it will displace. The carbon payback time depends on carbon intensity of manufacturing process and other phases during life time cycle in addition to emission factor or carbon intensity of fossil fuel power plant that are displaced by wind energy farms. It is function of where the wind turbine is made, size and technology as well as the site where it is installed and operate. The GPBT (in months) of a wind turbine can be determined from above definition (Louise, 2019), bearing in mind the average emission factor of Libyan power plants, including D\&T losses is $1.09 \mathrm{~kg} \mathrm{CO}_{2-\text { eq }} / \mathrm{kWh}$ (Olivier \& Peters, 2020).

\section{Avoided Emissions And Energy Savings}

The environmental aspects which can be avoided using wind energy can be determined as follows:

\section{1 avoided Carbon dioxide}

The amount of carbon dioxide that can be avoided from the proposed wind farm during the operation period can be determined by the knowledge of the amount of net energy produced from the wind farm during its life span (kWh) and the emission factor, which is for Libya is $1.09 \mathrm{~kg} \mathrm{CO}_{2-\text { eq }} / \mathrm{kWh}$ (Olivier \& Peters, 2020).

\subsection{Energy and money Savings:}

The amounts of energy savings can be determined from the fuel consumed annually by the conventional power plants that is equivalent to the energy produced by the proposed wind farm over its life time of 20 years $(2,084,920 \mathrm{MWh})$. The rate of fuel required to produce $1 \mathrm{MWh}$ is $\left(0.378 \mathrm{~m}^{3}\right)$ (Al-Behadili \& El-Osta, 2015). Therefore, the estimated fuel savings from the proposed wind farm can be determined. The energy savings would lead to money savings after knowing the oil prices.

\section{Results And Discussion}

\subsection{Calculation of Energy consumed on wind turbine Gamesa-114}

The results of life cycle analysis performed to the wind turbine Gamesa (G114-2.0MW) are presented and discussed as follows:

\subsubsection{Energy Consumed on Material's Manufacturing Process:}

Knowing all components/parts of the wind turbine as well as the material used and weights of these parts for the selected wind turbine from the manufacturer Gamesa (G114-2.0MW), and the specific energy values of the component's material, the energy consumed in the manufacturing process was calculated. 
Table (3) shows the results of energy consumed for different materials in a Gamesa- 2MW land-based wind turbine.

Table (3) the energy consumed on manufacturing process of the selected wind turbine (G114-2.0MW)

\begin{tabular}{|llll|}
\hline Material & Weight (g) & specific energy (MJ/kg ) & energy consumed (MJ) \\
\hline Low alloyed steel & 245049.27 & 34.00 & 8331689.8 \\
\hline High alloyed steel & 32319.7 & 53.00 & 1712944.1 \\
\hline Cast Iron & 48375 & 34.26 & 1657327.5 \\
\hline Copper & 1512.74 & 78.2 & 118296.3 \\
\hline Reinforcing steel & 41043.7 & 34.26 & 1406157.2 \\
\hline Aluminum & 4772.62 & 39.15 & 186848 \\
\hline Glass fiber & 22689.55 & 8.7 & 197399.1 \\
\hline Brass & 33.9 & 78.2 & 2650.98 \\
\hline Polymers & 4568.34 & 45.7 & 208773.14 \\
\hline GRP (Glass reinforced plastic) & 2605.39 & 8.7 & 22666.9 \\
\hline Concrete & 1112856 & 0.81 & 901413.36 \\
\hline Epoxy resin & 10743.41 & 45.7 & 490973.4 \\
\hline Miscellaneous & 9173.86 & 46.7 & 428419.3 \\
\hline Total energy consumed for one wind turbine (MJ) 15665559.08 & \\
\hline
\end{tabular}

\subsubsection{Energy Consumed on Recyclability.}

The average energy consumed on recyclability of Gamesa (G114-2.0MW) wind turbine depends on the kind of tower used. It depends on weight and type of material that is recyclable. Figure (3) shows the calculations of weights of main parts of the wind turbine: nacelle, rotor and tower.

Then the energy consumed on the recycling operations can be calculated by knowing the specific energy values for recycling components. The results are illustrated in table (4).

Table (4) energy consumed for Recyclability 


\begin{tabular}{|llll|}
\hline Material & $\begin{array}{l}\text { Weight } \\
(\mathbf{k g})\end{array}$ & $\begin{array}{l}\text { Specific energy (MJ/kg) } \\
\text { energy(MJ/kg) }\end{array}$ & $\begin{array}{l}\text { Energy consumed } \\
(\mathbf{M J})\end{array}$ \\
\hline $\begin{array}{l}\text { Different kinds of } \\
\text { steel }\end{array}$ & 314645.83 & 9.7 & 3052064.55 \\
\hline Copper & 1673.77 & 16.8 & 28119.34 \\
\hline Aluminum & 2031.03 & 6.4 & 12998.60 \\
\hline Total energy consumed on Recyclability (MJ) 3093182.48 & \\
\hline
\end{tabular}

\subsubsection{Energy consumed on landfilling operation}

The energy consumed on landfill operation was determined by the knowledge of weight of the remaining parts of the wind turbine for landfilling operations and the specific energy of each material, as it was explained in section (4.3). The weight of remaining part of the wind turbine was calculated as $1217392.85 \mathrm{~kg}$ and the energy consumed on the remaining parts of the wind turbine in landfilling process was determined as $48695.72 \mathrm{MJ}$.

\subsubsection{Energy consumed on Transportation}

In section (4.4) a scenario was suggested for the transportation of raw materials to the manufacturer and then to the site as a percentage of $5.81 \%$ from the energy consumed on manufacturing of the wind turbine. Therefore, the total energy consumed in the transport process was determined as $910169 \mathrm{MJ}$.

\subsubsection{The overall energy consumed on the turbine:}

The total primary energy consumed on the wind turbine can be determined as the summation of energy consumed in manufacturing, recycling, landfilling and transport as indicated in section (4.5). It was calculated as 19717606.28 MJ or 5477.113 MWh.

\subsection{Net energy analysisof wind turbine Gamesa-114, 2MW}

The Net energy analysis (NEA) included; the Energy Payback Ratio (EPBR), Energy Payback Period (EPBP) and Energy Intensity (EI). The Energy Payback Period (EPBP) and the Energy Payback Ratio (EPBR) were determined as in sections (5.1) and (5.2). Life time of the wind turbine was assumed as 20 years. The annual energy produced by one wind turbine is $10424.6 \mathrm{MWh} /$ year (Dow, 2015) and the total primary energy consumed on the wind turbine during its life time is $5477.113 \mathrm{MWh}$, as indicated in previous sections, which leads to an energy payback ratio of 38 years, which means that the wind farm will return back 38 times more energy than it consumes over its entire life cycle, and energy payback period of 6.3 months, which is comparable to a previous study (Al-Behadili \& El-Osta, 2015) and other literature such as: (Crawford, 2019; Chipindula, 2018; Haapala \& Prempreeda, 2014; Oebels \& Pacca, 2013; Abeliotis \& Pactiti, 2014; Vestas, 2007). The differences are due to site characteristics and wind potential, wind turbine performance, size and technology as well as all stages of life cycle primary energy consumption and where the wind turbine manufactured i.e. type of fuel that was used in these processes and type of transportation for these phases. Hence, the proposed wind farm will pay back all the energy it consumed 
in its entire life cycle in less than 7 months of its commissioning. Wind farm projects generally pay back the energy consumed throughout its life cycle within one year or less than of its commissioning. Modern wind turbines are more efficient, and use fewer materials, hence pay back the energy much quicker than the earlier designs. The energy intensity was evaluated according to equation as $0.0263 \mathrm{kWh}$ prim $/$ $\mathrm{kWh}_{\text {prod., }}$ which is comparable to values in other studies such as (Ardente et al., 2008) and (Palomo\& Gaillardon, 2009).

Modern wind turbines are more efficient and have less materials, and hence they pay back the energy much quicker than the earlier designs. The total energy produced by the Gamesa wind turbine during its life of 20 years would be $208492 \mathrm{MWh}$. The energy produced by the whole wind farm (10 turbines) will be $2084920 \mathrm{MWh}$. The Net energy from the proposed wind farm would be the difference between the energy produced and energy consumed on wind turbines. It was determined as 2030148.87 MWh.

\subsection{Life cycle emission (LCE)}

Energy and emission factors have been considered for all the required raw materials' production, recycling, landfilling and transport. Each factor has been determined by summing up the respective impact in every stage of the material's life cycle, as indicated in section (5.3).

The emission from different materials used for producing wind turbine Gamesa (G114-2.0MW) and emissions from recycling process are calculated and presented in Table (5) and Table (6) respectively, while emissions from landfilling and transport are presented in Table (7) and the total emissions from Gamesa (G114-2.0MW) are depicted in Table (8).

Table (5) Emissions from different materials used for manufacturing (G114-2.0MW)

\begin{tabular}{|llllllll|}
\hline & CO2 & CO & CH4 & N2O & SO2 & NOX & MNVOC \\
\hline Low steel & 606006.48 & 227.9 & 9.8 & 17.15 & 3553.21 & 2327.97 & 39.2 \\
\hline High steel & 105847.02 & 30.06 & 1.3 & 2.26 & 468.63 & 307.04 & 5.17 \\
\hline Cast iron & 193486.86 & 2372.28 & 8.942 & 6.26 & 591.95 & 257.52 & 334.43 \\
\hline Copper & 10108.84 & 2.248 & 0.247 & 0.294 & 55.075 & 35.86 & 0.386 \\
\hline Aluminum & 7071.56 & 1.54 & 0.144 & 0.226 & 43.23 & 26.76 & 0.308 \\
\hline GPR\&Glass & 14316.93 & 16.44 & 1.011 & 0.253 & 31.11 & 61.97 & 3.79 \\
\hline Concrete & 132452.12 & -- & 33.38 & 96.82 & 144.67 & 779 & - \\
\hline Miscellaneous & 42933.665 & 802.89 & 2.2 & 1.468 & 33.03 & 55.043 & 3.302 \\
\hline Total (kg) & 1112223.47 & 3453.36 & 57.024 & 124.73 & 4920.9 & 3851.162 & 386.58 \\
\hline
\end{tabular}

Table (6) Emissions from recycling materials 


\begin{tabular}{|ll|}
\hline Material & $\mathbf{C O}_{2}(\mathbf{k g})$ \\
\hline Steel & 572340.76 \\
\hline Aluminum & 1498.9 \\
Copper & 5742.7 \\
Total & $579582.36 \mathrm{~kg}$ \\
\hline
\end{tabular}

Table (7) Emission from landfilling \& transport

\begin{tabular}{|llllllll|}
\hline Kg & CO2 & CO & CH4 & N2O & SO2 & NOX & MNVOC \\
\hline Landfilling & 1095.65 & 12.174 & 48.695 & - & 2.434 & 12.174 & 12.174 \\
\hline Transport & 62701.54 & 109.220 & 1.547 & 5.006 & 7.190 & 146.9 & 214.982 \\
\hline
\end{tabular}

Table (8) Total emissions for Gamesa (G114-2.0MW)

\begin{tabular}{|llllllll|}
\hline & $\mathrm{CO}_{2}$ & $\mathrm{CO}$ & $\mathrm{CH}_{4}$ & $\mathrm{~N}_{2} \mathrm{O}$ & $\mathrm{SO}_{2}$ & $\mathrm{NO}_{\mathbf{x}}$ & MNVOC \\
\hline Material & 1112223.47 & 3453.36 & 57.024 & 124.73 & 4920.9 & 3851.162 & 386.58 \\
\hline Recycling & 579582.36 & - & - & - & - & - & - \\
\hline Landfilling & 1095.65 & 12.174 & 48.695 & - & 2.434 & 12.174 & 12.174 \\
\hline Transport & 62701.54 & 109.220 & 1.547 & 5.006 & 7.190 & 146.9 & 214.982 \\
\hline Total $(\mathrm{kg})$ & 1755603.02 & 3574.75 & 107.266 & 129.736 & 4930.52 & 4010.236 & 613.736 \\
\hline
\end{tabular}

The specific emissions during the lifecycle of Gamesa (G114-2.0MW) land-based wind turbine was calculated by dividing the total lifecycle emission by the lifecycle energy output in order to get the emission per (kWh) generated. The results are presented in table (9).

Table (9) Specific emissions (G114-2.0MW) land-based turbine. 


\begin{tabular}{|ll|}
\hline Pollutant & gm/kWh \\
\hline $\mathrm{CO}_{2}$ & 8.426148 \\
\hline $\mathrm{CO}$ & 0.017466 \\
\hline $\mathrm{CH}_{4}$ & 0.000515 \\
\hline $\mathrm{N}_{2} \mathrm{O}$ & 0.000236 \\
\hline $\mathrm{SO}_{2}$ & 0.023648 \\
\hline $\mathrm{NO}_{\mathrm{X}}$ & 0.019234 \\
\hline $\mathrm{NMVOC}$ & 0.002943 \\
\hline
\end{tabular}

Table (9) shows that the major pollutants are $\mathrm{CO}_{2}, \mathrm{SO}_{2}, \mathrm{NO}_{\mathrm{X}}$ and $\mathrm{CO}$ while Emission of $\mathrm{N}_{2} \mathrm{O}, \mathrm{CH}_{4}$, and NMVOC are marginal. It could be noticed that $\mathrm{CO}_{2}$, which is the main contributor to GHGs has the highest value. In this study, the $\mathrm{CO}_{2}$ intensity during life cycle of wind farm is $8.43 \mathrm{~g} / \mathrm{kWh}$. It is comparable with results in the literature (Chipindula, 2018; Haapala \& Prempreeda, 2014; Oebels \& Pacca, 2013; Abeliotis \& Pactiti, 2014; Jani \& Rangan, 2018; Ardente, 2008; Al-Behadili \& El-Osta, 2015). The manufacturing phase represented $63.35 \%$ of $\mathrm{CO}_{2}$ emissions, followed by recycling with $33 \%$, transportation $3.5 \%$ and a negligible share from land filling and operation and maintenance. Oebels et al. (Oebels \& Pacca, 2013), showed that the bulk emission share was from the production phase with $90 \%$ and transportation with $6 \%$ of $\mathrm{CO}_{2}$-emissions. The study also depicted that $\mathrm{CO}_{2}$-emissions was $7.1 \mathrm{gCO}_{2} / \mathrm{kWh}$ and that the $\mathrm{CO}_{2}$ emissions decreases with life time of wind turbines for both onshore and offshore and the carbon payback time decreases with increasing load factor.

There is a trend in the literature that its value decreases with size of wind turbines (Bhandari, 2020), but the size is not the only reason, in fact, the results are effected by other parameters such as rotor diameter, hub height, site wind potential and wind turbine performance (or capacity factor), wind turbine life time span .

In comparing wind power plants to other types of electricity generation plants, it was found that over life cycle, the nuclear power plants would generate $4 \mathrm{~g} \mathrm{CO}_{2} / \mathrm{kWh}$, coal CCS $\left(109 \mathrm{~g} \mathrm{CO}_{2} / \mathrm{kWh}\right)$, gas $\left(78 \mathrm{~g} \mathrm{CO}_{2}\right.$ / $\mathrm{kWh}$ ), hydro $97 \mathrm{~g} \mathrm{CO}_{2} / \mathrm{kWh}$, bioenergy $98 \mathrm{~g} \mathrm{CO}_{2} / \mathrm{kWh}$, while solar $6 \mathrm{~g} \mathrm{CO}_{2} / \mathrm{kWh}$ and wind $4 \mathrm{~g} \mathrm{CO}_{2} / \mathrm{kWh}$ and the global average target for $2{ }^{\circ} \mathrm{C}$ is $15 \mathrm{~g} \mathrm{CO}_{2} / \mathrm{kWh}$ (EVANS, 2021). This favors the use of wind energy.

\subsection{GHG Payback time:}

The GHG payback time was calculated according to section (5.3.2) and it is about two months. It is comparable to other studies (Louise, 2019). According to GWEC (GWEC, 2021), the $\mathrm{CO}_{2}$ payback period, for coal based power plant, is 5.4 months. The average GHG payback time of wind turbines in North west 
of Europe is about 5.3 months. (Louise, 2019). In general it is less than one year for all technologies (Bonou, 2016).

\subsection{Energy savings and avoided carbon dioxide: 7.5.1. Energy Savings:}

The amounts of energy savings were determined from the knowledge of the amount of fuel consumed annually by the conventional power plants that is equivalent to the energy produced by the proposed wind farm, as indicated in section (6). The rate of fuel required to produce $1 \mathrm{MWh}$ is $\left(0.378 \mathrm{~m}^{3}\right)$. Therefore, the estimated fuel savings from the proposed wind farm was determined as $788,099.76 \mathrm{~m}^{3}$ or 4.957 million bbl. of oil, which would lead to money savings of about 372 million US dollars, considering price of oil \$75 per barrel, as prices of (30-9-2021), (IEA, 2021b; Web, 2021).

\subsubsection{Avoided emissions:}

The amount of carbon dioxide and other emissions that can be avoided from the proposed farm due to the lack of emissions during the period of its operation was evaluated. From the previous section (7.2), the Net energy from the wind farm was determined as 2030148.87 MWh. The emission factors of Libyan power plants, for $\mathrm{CO}_{2}, \mathrm{CH}_{4}$ and $\mathrm{N}_{2} \mathrm{O}$ (main contributor to $\mathrm{GHGs}$ ), including emissions associated with the distribution and transmission losses, adopted from (Brander, 2011) are $1.017 \mathrm{~kg} \mathrm{CO} 2 / \mathrm{kWh}, 0.00003384$ $\mathrm{kg} \mathrm{CH}_{4} / \mathrm{kWh}$ and $0.0000061 \mathrm{~kg} \mathrm{~N}$ O/ $\mathrm{kWh}$ respectively. Therefore, the amount of carbon dioxide that can be avoided from one turbine in one year is $10.6 \mathrm{KtCO}_{2}$, while the amount for the proposed farm would be about $2 \mathrm{MtCO}_{2}$. The other emissions that could be avoided are $352.7 \mathrm{~kg} \mathrm{CH}_{4}$ and $63.5 \mathrm{~kg} \mathrm{~N} \mathrm{~N}_{2}$.

\section{Conclusions}

Wind energy has very low greenhouse gases emissions throughout its life cycle compared with other energy sources.

The LCA of the proposed wind farm prevailed that the total primary energy consumption over life cycle for one $2 \mathrm{MW}$ inland wind turbine is $5477.1 \mathrm{MWh}$, the electric energy generated by one wind turbine at the proposed site is 10,424.6 MWh/yr and of the whole wind farm over the 20 years life time of the wind turbine is 2,084,920 MWh. The energy performance of the wind farm is reasonable. It indicated that the energy payback time is 6.3 months, energy intensity $0.0263 \mathrm{kWh}$ prim $/ \mathrm{kWh}_{\text {prod }}$ and the energy payback ratio is 38. The environmental footprint analysis concentrated on two main global concerns; global warming and acidification effect. The greenhouse gases emissions are: carbon dioxide intensity is 8.4 $\mathrm{gms} / \mathrm{kWh}$, which is within the average values of international inland wind farms, methane $\left(\mathrm{CH}_{4}\right)$ is $0.000519 \mathrm{gm} / \mathrm{kWh}$ and nitrous oxide $\left(\mathrm{N}_{2} \mathrm{O}\right)$ is $0.000236 \mathrm{gm} / \mathrm{kWh}$. Emissions that contribute to acidification: $\mathrm{SO}_{2}$ is $0.02365 \mathrm{gm} / \mathrm{kWh}$ and $\mathrm{NOX}$ is $0.0192 \mathrm{gm} / \mathrm{kWh}$. The avoided $\mathrm{GHG}$ emissions $\mathrm{CO}_{2}$, $\mathrm{CH}_{4}$, and $\mathrm{N}_{2} \mathrm{O}$ were determined as 2 Mtons, $352.7 \mathrm{~kg}$ and $63.5 \mathrm{~kg}$ respectively. This can be translated to money savings. The fuel savings was determined as 4.96 million barrel of oil and therefore money 
savings was calculated as 367 million US dollars, which could be invested in wind farms development. The primary energy consumption for manufacturing represented the highest share of $79.4 \%$, followed by recycling $15.6 \%$ and transportation $4.61 \%$, with negligible share from land filling and operation and maintenance. The manufacturing phase represented $63.35 \%$ of $\mathrm{CO}_{2}$ emissions, followed by recycling with $33 \%$, transportation $3.5 \%$ and a negligible share from land filling and operation and maintenance. Comparing these results with other studies in the literatures, it could be concluded that the main indicators of LCA for the performance of wind farms are dependent on site, technology and size of wind turbines as well as energy consumed during life cycle of the project, which depends on the sites where the wind turbine is manufactured and type of transportation and distance traveled by different parts and components of a wind turbine.

Future work might consider outputs from the life-cycle stages such as emissions to air, water consumption, visual impacts, shadow flicker, noise, and a potential impact on bird and bat fatalities.

\section{Declarations}

\section{Data availability:}

The datasets produced and analyzed in this study are available from the authors upon reasonable request.

\section{Author contribution statement:}

All authors contributed to conception and design of the study. Data collection and analysis was performed by [A. Aboulqassim]; investigation by [W. Elosta]; Writing- original draft preparation [W. Elosta]; Writing- review and editing [all authors]; All authors read and approved the final manuscript.

\section{Declaration of competence of interest:}

The authors declare that they have no competing interest of any kind or personal relationship that would influence the work performed in this study.

\section{Funds:}

This study did not receive any external funds or grants.

\section{Acknowledgments:}

The authors would like to appreciate the help and support of Center for Solar Energy Research and Studies and University of Zawia.

\section{References}


1. Abeliotis K, Pactiti D (2014) Assessment of the environmental impacts of a wind farm in central Greece during its life cycle. International Journal of Renewable Energy Research 4(3):580-585. https://doi.org/10.20508/ijrer.28148

2. Aboulqassim AA (2017) Environmental Assessment of Proposed Wind Farm in Zawia City. University of Zawia

3. Al-Behadili SH, El-Osta W (2015) Life Cycle Assessment of Dernah (Libya) wind farm. Renewable Energy 83:1227-1233. https://doi.org/10.1016/j.renene.2015.05.041

4. Ardente F, Beccali M, Cellura M, Lo Brano V (2008) Energy performances and life cycle assessment of an Italian wind farm. Renew Sustain Energy Rev 12(1):200-217.

https://doi.org/10.1016/j.rser.2006.05.013

5. Bhandari R, Kumar B, Mayer F (2020) Life cycle greenhouse gas emission from wind farms in reference to turbine sizes and capacity factors. J Clean Prod 277:123385. https://doi.org/10.1016/j.jclepro.2020.123385

6. Bonou A, Laurent A, Olsen SI (2016) Life cycle assessment of onshore and offshore wind energyfrom theory to application. Appl Energy 180:327-337.

https://doi.org/10.1016/J.APENERGY.2016.07.058

7. Brander AM, Sood A, Wylie C, Haughton A, Lovell J, Reviewers I, Davis G (2011) Electricity-specific emission factors for grid electricity. Ecometrica, August,1-22

8. Chipindula J, Botlaguduru VSV, Du H, Kommalapati RR, Huque Z (2018) Life cycle environmental impact of onshore and offshore wind farms in Texas. Sustainability (Switzerland) 10(6):1-18. https://doi.org/10.3390/su10062022

9. Crawford RH (2019) Life cycle energy and greenhouse emissions analysis of wind turbines and the effect of size on energy yield Life cycle energy and greenhouse emissions analysis of wind turbines and the effect of size on energy yield. https://doi.org/10.1016/j.rser.2009.07.008. August

10. David R, Wilburn (2011) Wind Energy in the United States and Materials Required for the Land-Based Wind Turbine Industry From 2010 Through 2030, Scientific Investigations Report 2011-5036

11. Dow JM (2015) Technical-Economic Analysis of Wind Farm Potential Construction in the ZawiaCity 2015

12. EVANS S (2021) Solar, wind and nuclear have 'amazingly low' carbon footprints, study finds. https://www.carbonbrief.org/solar-wind-nuclear-amazingly-low-carbon-footprints

13. Gamesa (2017) Electricity from a European G114-2.0 MW On-shore Wind Farm: Gameas 2017 EPD report

14. Guezuraga B, Zauner R, Pölz W (2012) Life cycle assessment of two different 2 MW class wind turbines. Renewable Energy, Elsevier 37(1):37-44

15. GWEC (2021) GWEC- Global wind report 2021

16. Haapala KR, Prempreeda P (2014) Comparative life cycle assessment of $2.0 \mathrm{MW}$ wind turbines. International Journal of Sustainable Manufacturing 3(2):170-185. 
https://doi.org/10.1504/IJSM.2014.062496

17. IEA (2021) Key World Energy Statistics. IEA

18. Jani D, Rangan B (2018) Life cycle energy and carbon footprint analysis of large MW scale grid connected wind power systems in India. E3S Web of Conferences, 64.

https://doi.org/10.1051/e3sconf/20186408002

19. Kadiyala A, Kommalapati R, Huque Z (2017) Characterization of the life cycle greenhouse gas emissions from wind electricity generation systems. International Journal of Energy and Environmental Engineering 8(1):55-64. https://doi.org/10.1007/s40095-016-0221-5

20. Karkour S, Rachid S, Maaoui M, Lin CC, Itsubo N (2021) Status of life cycle assessment (LCA) in Africa. Environments - MDPI 8(2):1-46. https://doi.org/10.3390/environments8020010

21. KFW GIZ, IRENA F (2021) The Renewable Energy Transition in Africa: Powering Access, Resilience and Prosperity / KFW, GIZ, IRENA, FMECD, 2021

22. Lenzen M, Wachsmann U (2004) Wind turbines in Brazil and Germany: an example of geographical variability in life-cycle assessment. 77(2004), 119-130. https://doi.org/10.1016/S03062619(03)00105-3

23. Louise C, Dammeier, Loriaux JM, Steinmann ZJN, Smits DA, Wijnant IL, van den Hurk B, Huijbregts MAJ (2019) Space, Time, and Size Dependencies of Greenhouse Gas Payback Times of Wind Turbines in Northwestern Europe. Environ Sci Technol 53:9289-9297

24. Maria Tsagkaraki (2015) Comparative Life Cycle Assessment of selected renewable electricity generation technologies. Aalborg University

25. Martínez E, Sanz F, Pellegrini S, Jiménez E, Blanco J (2008) Life-cycle assessment of a 2-MW rated power wind turbine: CML method. The International Journal of Life Cycle Assessment 2008 14:1(1):52-63. https://doi.org/10.1007/S11367-008-0033-9. 14

26. Nian V, Liu Y, Zhong S (2019) Life cycle cost-benefit analysis of offshore wind energy under the climatic conditions in Southeast Asia - Setting the bottom-line for deployment. Appl Energy 233234:1003-1014. https://doi.org/10.1016/j.apenergy.2018.10.042

27. Oebels KB, Pacca S (2013) Life cycle assessment of an onshore wind farm located at the northeastern coast of Brazil. Renewable Energy 53:60-70.

https://doi.org/10.1016/J.RENENE.2012.10.026

28. Olivier JGJ, Peters JAHW (2020) TRENDS IN GLOBAL CO2 AND TOTAL GREENHOUSE GAS EMISSIONS 2020 Report

29. Palomo B, Gaillardon B (2009) LIFE CYCLE ASSESSMENT OF A FRENCH WIND Abstract.

30. Rashedi A, Sridhar I, Tseng KJ (2013) Life cycle assessment of $50 \mathrm{MW}$ wind firms and strategies for impact reduction. Renew Sustain Energy Rev 21:89-101. https://doi.org/10.1016/j.rser.2012.12.045

31. Razdan P, Garrett P (2015) Life Cycle Assessment of Electricity Production from an onshore V110-2.0 MW Wind Plant, December 2015 
32. Tremeac B, Meunier F (2009) Life cycle analysis of $4.5 \mathrm{MW}$ and $250 \mathrm{~W}$ wind turbines. Renew Sustain Energy Rev 13(8):2104-2110. https://doi.org/10.1016/j.rser.2009.01.001

33. Vestas (2007) An environmentally friendly investment: Lifecycle Assessment of a V80-2.0 MW onshore wind turbine

34. Wagner H, Baack C, Eickelkamp T, Epe A, Lohmann J, Troy S (2011) Life cycle assessment of the offshore wind farm alpha ventus. Energy 36(5):2459-2464.

https://doi.org/10.1016/j.energy.2011.01.036

35. web (2021a) https://globalwindatlas.info/area/Libya. https://globalwindatlas.info/area/Libya

36. web (2021b) https://markets.businessinsider.com/commodities/oil-price?type=wti.

https://markets.businessinsider.com/commodities/oil-price?type=wti

37. Web (2021a) Environment. https://www.wind-energy-the-facts.org/index-6.html

38. Web (2021b) https://www.bloomberg.com/energy. https://www.bloomberg.com/energy

39. Web (2021c) Why and when? - Consequential LCA. https://consequential-lca.org/clca/why-andwhen/

40. Weinzettel J, Reenaas M, Solli C, Hertwich EG (2009) Life cycle assessment of a floating offshore wind turbine. Renewable Energy 34(3):742-747. https://doi.org/10.1016/j.renene.2008.04.004

\section{Figures}

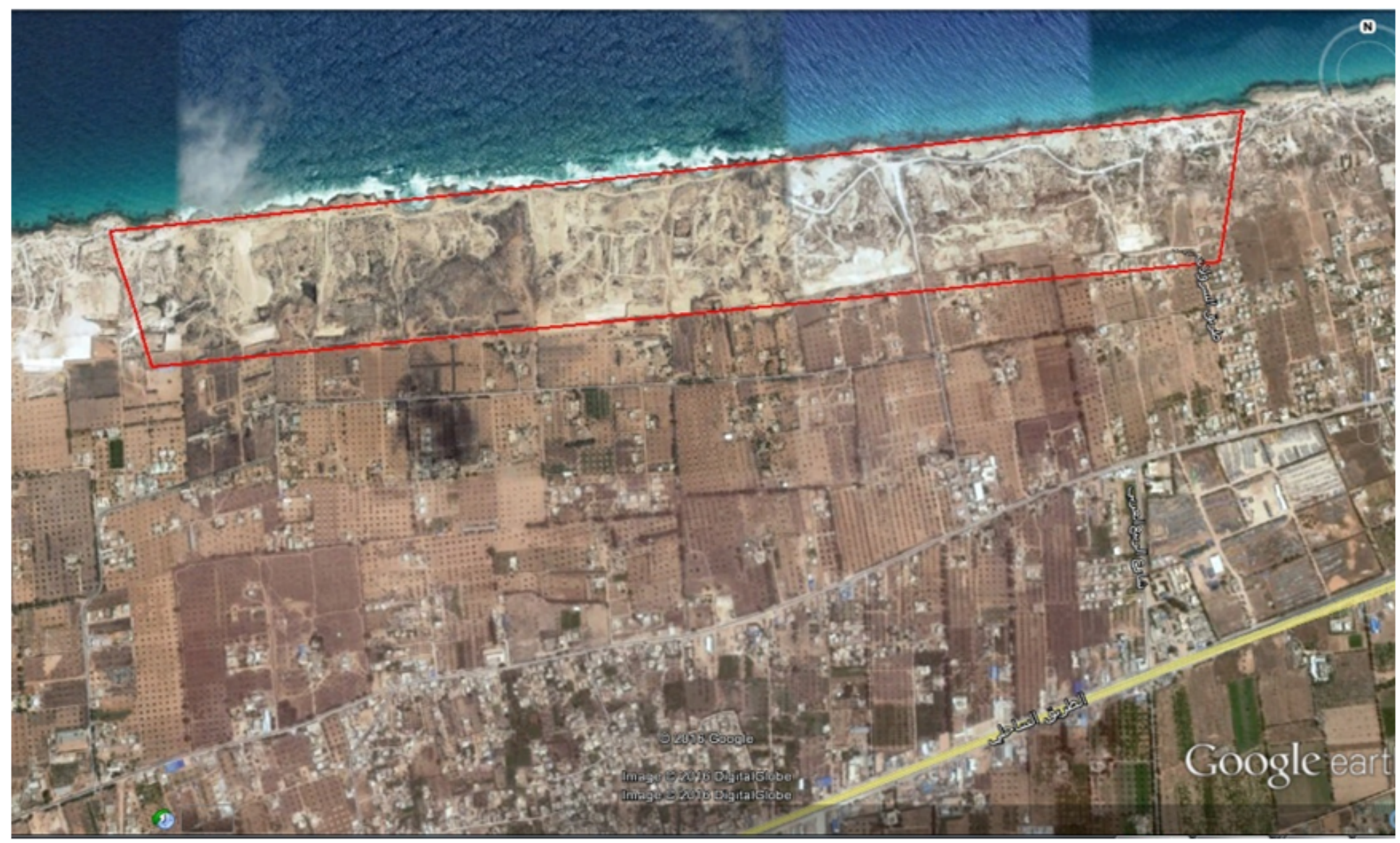


Figure 1

Site of the proposed wind farm.

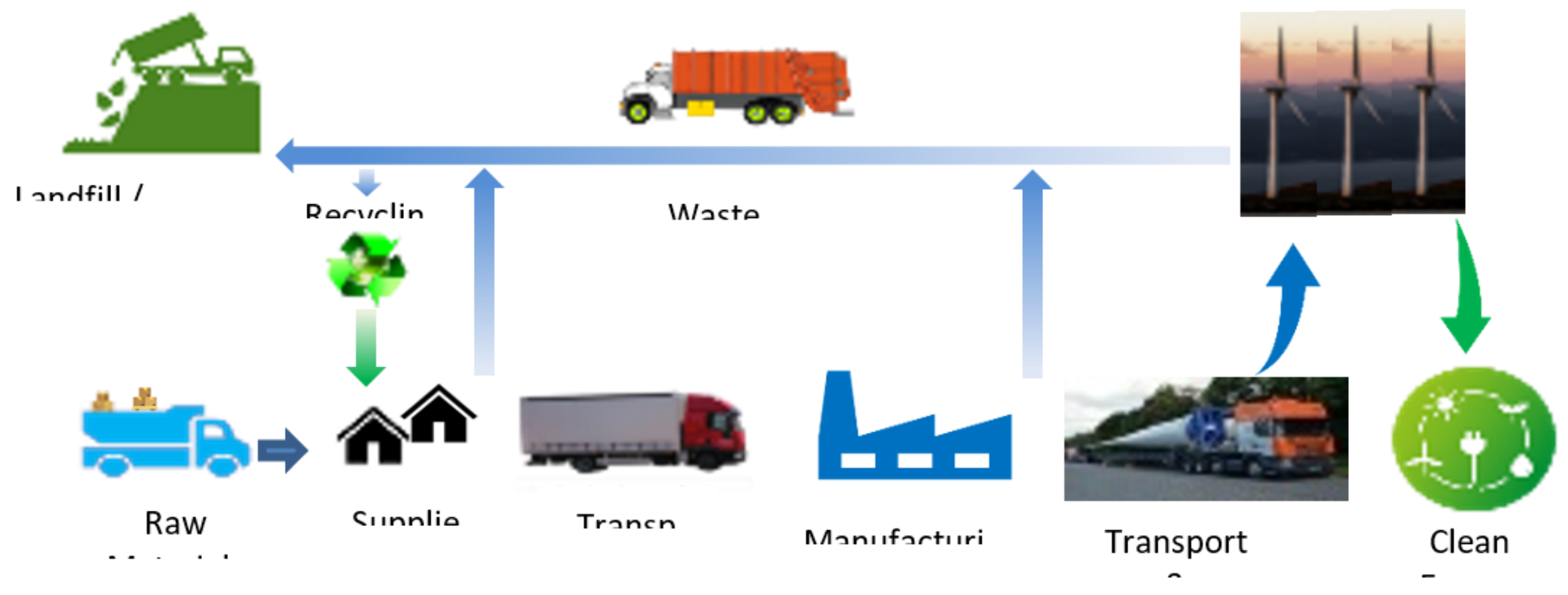

Figure 2

Life cycle of energy consumption of the proposed wind farm.

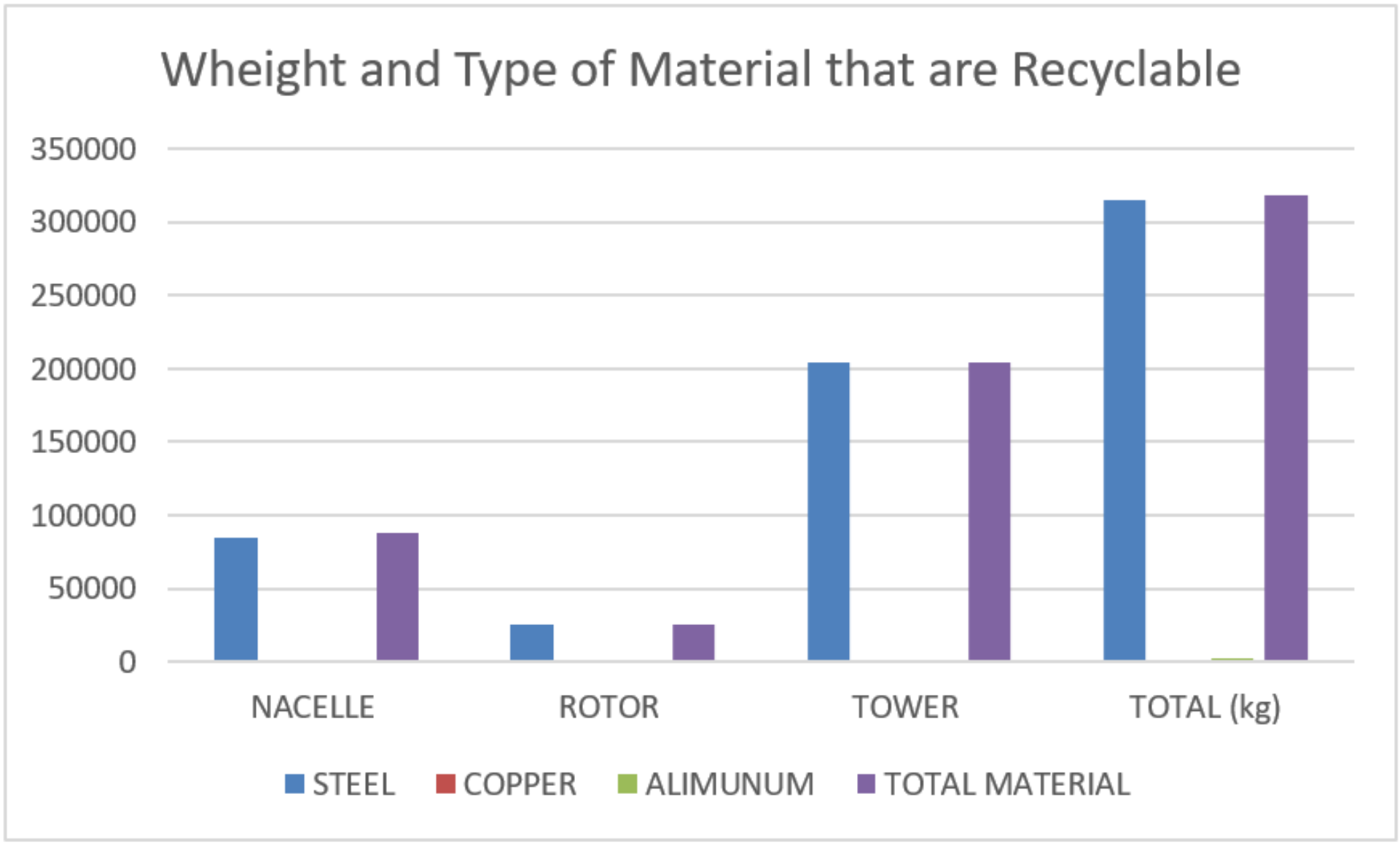

Figure 3 
Weights and type of materials that are Recyclable

\section{Supplementary Files}

This is a list of supplementary files associated with this preprint. Click to download.

- Graphicalabstract1.docx 